\title{
PEMBELAJARAN SAINTIFIK ELEKTRONIKA DASAR BERORIENTASI PEMBELAJARAN BERBASIS MASALAH
}

\author{
Resti Fauziah, Ade Gafar Abdullah, Dadang Lukman Hakim \\ Program Studi Pendidikan Teknik Elektro FPTK UPI \\ Jalan Dr. Setiabudhi No. 207 Bandung 40154 \\ E-mail: resti.fauziah@gmail.com
}

\begin{abstract}
Abstrak. Implementasi kurikulum baru sangat menonjolkan pendekatan saintifik dengan pembelajaran berpusat pada peserta didik. Perancangan skenario pembelajaran berbasis pendekatan saintifik memerlukan hasil riset implementasi di kelas. Penelitian bertujuan untuk mengembangkan rencana pelaksanaan pembelajaran elektronika dasar di Sekolah Menengah Kejuruan. Pengembangan rencana pelaksanaan pembelajaran bercirikan pembelajaran saintifik, mengadopsi pendekatan problem based learning. Metode yang digunakan pada penelitian ini yaitu metode pengungkapan pendapat dan observasi. Teknik pengumpulan data dilakukan dengan menggunakan angket, observasi dan wawancara. Penelitian ini menghasilkan RPP berbasis pendekatan saintifik melalui model problem based learning, dan mendapat tanggapan positif dari guru dan peserta didik, sehingga berdampak positif terhadap peningkatan hard dan soft skill peserta didik .
\end{abstract}

Kata Kunci: elektronika dasar, pendekatan saintifik, pembelajaran berbasis masalah.

\begin{abstract}
The implementation of the new 2013 curriculum 2013 highly recommends scientific approach in which learning is centered to student. The design of scientific learning lesson plan requires classroom implementation research. The research aims to develop a lesson plan of basic electronics learning in a vocational high school. The lesson plan is developed to characterize a scientific learning, adopting the problem-based learning. The research was conducted using brainstorming and observation method. The data was collected through questionnaires, observations, and interviews. Research has produced scientific-approach-based lesson plans with problem-based learning models, and has received positive feedbacks from teachers and students, so that effects an improvement in students' hard skill and soft skill.
\end{abstract}

Keywords: basic electronic, 2013 curriculum, scientific approach, problem-based learning.

\section{PENDAHULUAN}

Kurikulum merupakan salah satu unsur sumberdaya pendidikan yang memberikan kontribusi signifikan untuk mewujudkan proses berkembangnya kualitas potensi peserta didik. Kurikulum 2013 didesain berdasarkan pada budaya dan karakter bangsa, berbasis peradaban, dan berbasis pada kompetensi. Berdasarkan pengalaman pada Program Pengalaman Lapangan (PPL) dan hasil observasi yang dilaksanakan di SMK Negeri 1 Cimahi program keahlian Teknik Elektronika Industri (TEI) pada standar kompetensi menerapkan dasar-dasar elektronika, peneliti menemukan permasalahan pada proses pembelajaran serta pemahaman penguasaan pada standar 
kompetensi. Adanya aktivitas belajar peserta didik yang kurang optimal, jelas mengindikasikan adanya permasalahan serius dalam kegiatan pembelajaran elektronika dasar yang harus segera dicarikan solusinya. Sebagai upaya pemecahan terhadap masalah yang timbul dalam proses pembelajaran elektronika dasar tersebut maka dilakukanlah pendekatan saintifik menggunakan model pembelajaran Problem Based Learning (PBL).

Proses pembelajaran pada kurikulum 2013 untuk semua jenjang dilaksanakan dengan menggunakan pendekatan saintifik yaitu pendekatan pembelajaran yang berpusat pada peserta didik yang memiliki kriteria pendekatan saintifik sebagai berikut (Permendikbud, 2013): (1) Materi pembelajaran berbasis pada fakta atau fenomena yang dapat dijelaskan dengan logika atau penalaran tertentu, bukan sebatas kira-kira, khayalan, legenda, atau dongeng semata. (2) Penjelasan guru, respon peserta didik, dan interaksi edukatif guru-peserta didik terbebas dari prasangka yang serta-merta, pemikiran subjektif, atau penalaran yang menyimpang dari alur berpikir logis. (3) Mendorong dan menginspirasi peserta didik berpikir secara kritis, analistis, dan tepat dalam mengidentifikasi, memahami, memecahkan masalah, dan mengaplikasikan materi pembelajaran. (4) Mendorong dan menginspirasi peserta didik mampu berpikir hipotetik dalam melihat perbedaan, kesamaan, dan tautan satu sama lain dari materi pembelajaran. (5) Mendorong dan menginspirasi peserta didik mampu memahami, menerapkan, dan mengembangkan pola berpikir yang rasional dan objektif dalam merespon materi pembelajaran. (6) Berbasis pada konsep, teori, dan fakta empiris yang dapat dipertanggungjawabkan. (7) Tujuan pembelajaran dirumuskan secara sederhana dan jelas, namun menarik sistem penyajiannya.

Kurikulum 2013 menekankan pada dimensi pedagogik modern dalam pembelajaran, yaitu menggunakan pendekatan ilmiah. Pendekatan ilmiah (scientific appoach) meliputi mengamati, menanya, mencoba, mengolah, menyajikan, menyimpulkan, dan mencipta untuk semua mata pelajaran (Permendikbud, 2013).

Metode mengamati sangat bermanfaat bagi pemenuhan rasa ingin tahu peserta didik. Sehingga proses pembelajaran memiliki kebermaknaan yang tinggi. Dengan metode observasi peserta didik menemukan fakta bahwa ada hubungan antara obyek 
yang dianalisis dengan materi pembelajaran yang digunakan oleh guru. Melalui mengamati gambar, peserta didik dapat secara langsung menceritakan kondisi sebagaimana yang di tuntut dalam Kompetensi Dasar (KD) dan indikator, dan mata pelajaran apa saja yang dapat dipadukan dengan media yang tersedia (Permendikbud, 2013).

Peserta didik tidak mudah menanya apabila tidak dihadapkan dengan media yang menarik. Guru harus mampu menginspirasi peserta didik untuk mau dan mampu menanya. Pada saat guru mengajukan pertanyaan, guru harus membimbing dan memandu peserta didik menanya dengan baik. Ketika guru menjawab pertanyaan, guru mendorong peserta didik menjadi penyimak yang baik. Pertanyaan guru dimaksudkan untuk memperoleh tanggapan verbal (Permendikbud, 2013).

Istilah "menalar" dalam kerangka proses pembelajaran dengan pendekatan ilmiah yang dianut dalam kurikulum 2013 untuk menggambarkan bahwa guru dan peserta didik merupakan pelaku aktif. Titik tekannya dalam banyak hal dan situasi peserta didik harus lebih aktif daripada guru. Penalaran adalah proses berfikir yang logis dan sistematis atas fakta-kata empiris yang dapat diobservasi untuk memperoleh simpulan berupa pengetahuan. Penalaran dimaksud merupakan penalaran ilmiah, meski penalaran nonilmiah tidak selalu tidak bermanfaat. Menalar merupakan proses berfikir yang logis dan sistematis atas fakta-fakta empiris yang dapat diobservasi untuk memperoleh simpulan berupa pengetahuan. Menalar (associating) merujuk pada teori belajar asosiasi, yaitu kemampuan mengelompokkan beragam ide dan mengasosiasikan beragam peristiwa untuk kemudian memasukannya menjadi penggalan memori dalam otak dan pengalaman-pengalaman yang tersimpan di memori otak berinteraksi dengan pengalaman sebelumnya (asosiasi) (Permendikbud, 2013).

Mencoba merupakan keterampilan proses untuk mengembangkan pengetahuan tentang alam sekitar dengan menggunakan metode ilmiah dan sikap ilmiah dalam memecahkan masalah-masalah yang dihadapinya sehari-hari. Untuk memperoleh hasil belajar yang otentik, peserta didik harus melakukan percobaan, terutama untuk materi/substansi yang sesuai dan aplikasi dari kegiatan mencobapun dimaksudkan untuk mengembangkan berbagai ranah tujuan belajar (sikap, keterampilan, dan 
pengetahuan). Aplikasi metode eksperimen atau mencoba dimaksudkan untuk mengembangkan berbagai ranah tujuan belajar, yaitu sikap, keterampilan, dan pengetahuan. Aktivitas pembelajaran yang nyata untuk ini yaitu: menentukan tema atau topik sesuai dengan kompetensi dasar menurut tuntutan kurikulum, mempelajari cara-cara penggunaan alat dan bahan yang tersedia dan harus disediakan, mempelajari dasar teoritis yang relevan dan hasil-hasil eksperimen sebelumnya, melakukan dan mengamati percobaan, mencatat fenomena yang terjadi, menganalisis, dan menyajikan data, menarik simpulan atas hasil percobaan, dan membuat laporan dan mengkomunikasikan hasil percobaan (Permendikbud, 2013).

Membentuk jejaring terdiri dari tiga langkah yaitu: menyimpulkan, menyajikan dan mengkomunikasikan. Menyimpulkan dapat dilakukan bersama-sama dalam satu kesatuan kelompok, atau bisa juga dengan dikerjakan sendiri setelah mendengarkan hasil kegiatan mengolah informasi. Menyajikan dapat disajikan dalam bentuk laporan tertulis. Laporan tertulis dapat dijadikan sebagai salah satu bahan untuk portofolio kelompok dan atau individu dan walaupun tugas dikerjakan secara berkelompok, sebaiknya hasil pencatatan dilakukan oleh setiap individu agar dapat dimasukan ke dalam file portofolio peserta didik. Pada kegiatan akhir diharapkan peserta didik dapat mengkomunikasikan hasil pekerjaan yang telah disusun secara bersama-sama dalam kelompok dan/atau secara individu. Guru dapat memberikan klarifikasi agar peserta didik mengetahui dengan tepat apakah yang telah dikerjakan sudah benar atau ada yang harus diperbaiki. Kegiatan mengkomunikasikan dapat diarahkan sebagai kegiatan konfirmasi (Permendikbud, 2013).

Model pembelajaran PBL merupakan salah satu pendekatan pembelajaran yang dianggap memiliki karakteristik pembelajaran saintifik. Pada PBL, peserta didik dituntut aktif untuk mendapatkan konsep yang dapat diterapkan dengan jalan memecahkan masalah, peserta didik akan mengeksplorasi sendiri konsep-konsep yang harus mereka kuasai, dan peserta didik diaktifkan untuk bertanya dan beragumentasi melalui diskusi, mengasah keterampilan investigasi, dan menjalani prosedur kerja ilmiah lainnya (Permana, 2010).

PBL diyakini sangat cocok untuk pembelajaran disiplin ilmu teknik, karena 
metodologinya memelihara pemikiran kritis dan keterampilan pemecahan masalah, hal tersebut sangat penting dalam karir lulusan di bidang teknik (S.M. Said dkk, 2005) Berdasarkan respon peserta didik yang mendalami ilmu keteknikan bahwa PBL memberikan dua kali keuntungan daripada pembelajaran tradisional, sehinggap PBL sangat direkomendasikan dalam pembelajaran keteknikan (Aman Yadav, 2011). Dalam PBL, guru dan peserta didik perlu memainkan peran yang berbeda dari pembelajaran tradisional .Untuk keberhasilan PBL diperluka waktu khusus untuk menyampaikan intruksi pembelajaran . Alokasi waktu yang sedikit akan membatasi aspek interaktif dan kooperatif, sedangkan pekerjaan rumah harus dirancang dengan cermat sehingga dapat memotivasi peserta didik . Peserta didik merasa terlibat dalam proses belajar melalui PBL karena mereka terus bekerja. Pada pelaksanaan awal PBL guru harus mempersiapkan skenario pembelajaran yang matang (Karim J Nasr, 2004)

\section{METODE}

Metode yang digunakan pada penelitian ini yaitu metode kombinasi antara pre-experimental design dengan desain penelitian one-shot case study. Populasi yang digunakan dalam penelitian ini yaitu peserta didik kelas X program keahlian TEI di SMK Negeri 1 Kota Cimahi periode 2013-2014 yang sedang menempuh mata pelajaran Elektronika Dasar. Adapun teknik penentuan sampel dalam penelitian ini adalah dengan menggunakan teknik sampling purposive. Teknik ini sangat cocok untuk digunakan dalam penelitian ini karena jumlah sampel yang diambil hanya pada peserta didik kelas X program keahlian TEI di SMK Negeri 1 Kota Cimahi periode 2013-2014. Sampel penelitian ini yaitu kelas X TEI B yang berjumlah 34 orang.

\section{HASIL DAN PEMBAHASAN}

\section{RPP Berbasis Pendekatan Saintifik Melalui Model Pembelajaran PBL}

RPP berbasis pendekatan saintifik melalui model pembelajaran PBL yang dibuat sebagai produk penelitian ini mengacu kepada salinan lampiran peraturan Menteri Pendidikan dan Kebudayaan Republik Indonesia nomor 65 (2013). Komponen RPP meliputi materi induktansi di pertemuan pertama, hukum ohm dan rangkaian seri 
di pertemuan kedua. Sistematika RPP terdiri dari : Identitas Sekolah, Identitas Mata Pelajaran, Kelas/Semester, Materi Pokok, Alokasi Waktu, Kompetensi Inti, Kompetensi Dasar, Indikator Pencapaian Kompetensi , Tujuan Pembelajaran , Materi Pembelajaran, Metode Pembelajaran , Media pembelajaran dan Sumber Belajar.

Langkah-langkah pembelajaran pada kegiatan inti mengacu kepada tahapan model pembelajaran PBL yaitu penyampaian konsep dasar, pendefinisian masalah, pembelajaran mandiri, pertukaran pengetahuan dan penilaian yang didalamnya terdapat tahapan-tahapan pendekatan saintifik terdapat pada tabel 1.

Tabel 1. Langkah pembelajaran pendekatan saintifik melalui model pembelajaran PBL

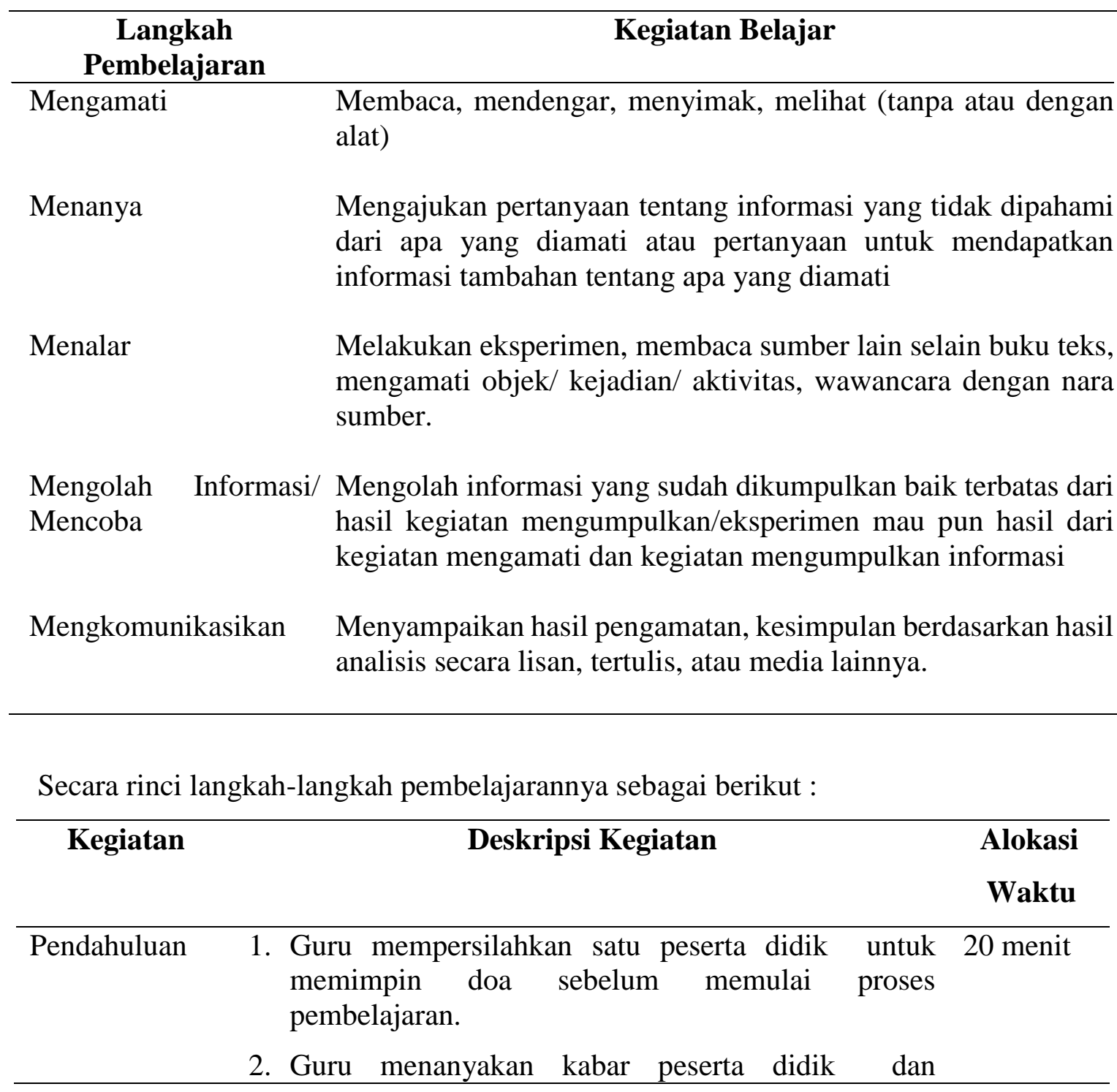


mengabsen kehadiran peserta didik .

3. Guru memberikan semangat kepada peserta didik agar proses pembelajaran lebih menyenangkan.

4. Guru menyampaikan tujuan pembelajaran yang ingin dicapai agar peserta didik dapat memahami pembelajaran induktansi.

5. Guru memberikan gambaran tentang pentingnya memahami karakteristik induktor dan memberikan gambaran tentang aplikasi nya dalam kehidupan sehari-hari.

6. Sebagai apersepsi untuk mendorong rasa ingin tahu dan berpikir kritis, peserta didik diajak memecahkan masalah mengenai teori induktansi.

1. Guru menjelaskan model pembelajaran yang akan digunakan dalam pembelajaran teori induktansi yaitu model pembelajaran PBL (Problem Based Learning) agar peserta didik paham langkah-langkah yang akan dijalani selama proses pembelajaran.

2. Guru memberikan teori medan magnet sebagai teori pendukung untuk mendasari pemahaman peserta didik terhadap teori induktansi.

\section{Pendefinisian Masalah}

3. Guru menunjukan contoh gambar speaker dan relay untuk diamati, ditanya dan ditalar oleh peserta didik .

4. Guru membagi peserta didik dalam 7 kelompok yang terdiri dari 5 peserta didik .

5. Guru membagikan nomor urut 1 sampai 5 kepada setiap peserta didik .

6. Guru memberikan permasalahan mengenai pengertian, fungsi, dan simbol-simbol induktor kepada peserta didik bernomor urut 1.

7. Guru memberikan permasalahan mengenai macam-macam induktor, fungsinya dan pengaplikasiannya dalam kehidupan sehari-hari kepada peserta didik bernomor urut 2. 
8. Guru memberikan permasalahan mengenai induktansi searah dan induktansi bolak-balik kepada peserta didik bernomor urut 3 .

9. Guru memeberikan permasalahan mengenai raktansi induktif dan hubungan antara $\mathrm{X}_{\mathrm{L}}$ dengan $\mathrm{F}$ (frekwensi) kepada peserta didik bernomor urut 4 .

10. Guru memberikan permasalahan mengenai prinsip kerja pengisian dan pengosongan induktor kepada peserta didik bernomor urut 5 .

11. Selama peserta didik bekerja di dalam kelompok, guru memperhatikan dan mendorong semua peserta didik untuk terlibat diskusi, dan mengarahkan bila ada kelompok yang melenceng jauh pekerjaannya.

\section{Pembelajaran Mandiri}

12. Peserta didik mencari berbagai referensi atau sumber untuk memperjelas jawaban dari permasalahan yang sudah diperoleh.

13. Peserta didik mengadakan diskusi dengan teman berbeda kelompok untuk bertukar informasi dan berdiskusi mengenai hasil dari permasalahan yang telah diperoleh.

14. Peserta didik mendalami materi sesuai dengan permasalahan yang telah diterima sebelumnya.

\section{Pertukaran Pengetahuan}

15.Peserta didik kembali berkelompok untuk mendiskusikan hasil temuan dari berbagai sumber.

16. Salah satu peserta didik dari setiap kelompok diskusi (tidak harus yang terbaik) diminta untuk mempresentasikan hasil diskusinya ke depan kelas. Sementara kelompok lain, menanggapi dan menyempurnakan apa yang dipresentasikan.

17. Guru mengumpulkan semua hasil diskusi tiap kelompok.

18. Dengan tanya jawab, guru mengarahkan semua peserta didik pada kesimpulan karakteristik induktor pada rangkaian. 
19. Guru memberikan soal yang terkait dengan karakteristik induktor untuk dikerjakan tiap peserta didik, dan dikumpulkan.

Penutup 1. Peserta didik diminta menyimpulkan tentang 20 menit bagaimana karakteristik induktor.

2. Dengan bantuan presentasi komputer, guru menayangkan apa yang telah dipelajari dan disimpulkan mengenai karakteristik induktor.

3. Guru memberikan tugas PR mengenai penerapan induktor pada alat-alat elektronika yang terdapat di lingkungan sekitar.

4. Guru mengakhiri kegiatan belajar dengan memberikan pesan untuk tetap belajar.

Kegiatan pendahuluan, guru menyiapkan peserta didik secara psikis dan fisik untuk mengikuti proses pembelajaran, memberi semangat motivasi belajar peserta didik secara kontekstual sesuai manfaat dan aplikasi materi ajar dalam kehidupan sehari-hari, dengan memberikan contoh dan perbandingan lokal, nasional dan internasional, mengajukan pertanyaan-pertanyaan yang mengaitkan pengetahuan sebelumnya dengan materi yang akan dipelajari, memusatkan perhatian peserta didik pada materi yang akan dibelajarkan dengan cara menampilkan slide animasi mengenai induktor, menjelaskan tujuan pembelajaran atau kompetensi dasar yang akan dicapai dalam pembelajaran induktansi, dan memberikan persepsi awal kepada peserta didik tentang materi yang akan diajarkan.

Kegiatan inti menggunakan model pembelajaran, metode pembelajaran, media pembelajaran, dan sumber belajar yang disesuaikan dengan karakteristik peserta didik dan mata pelajaran. Pemilihan pendekatan saintifik pembelajaran yang menghasilkan karya berbasis pemecahan masalah (problem based learning) disesuaikan dengan karakteristik kompetensi dan jenjang pendidikan. Pada kegiatan inti mencakup aspek-aspek : (1) Sikap : sesuai dengan karakteristik sikap, maka salah satu alternatif yang dipilih adalah proses afeksi mulai dari menerima, menjalankan, menghargai, menghayati, hingga mengamalkan. Seluruh aktivitas pembelajaran berorientasi pada 
tahapan kompetensi yang mendorong peserta didik untuk melakuan aktivitas tersebut. (2) Pengetahuan : melalui aktivitas mengetahui, memahami, menerapkan, menganalisis, mengevaluasi, hingga mencipta. Karakteritik aktivititas belajar dalam domain pengetahuan ini memiliki perbedaan dan kesamaan dengan aktivitas belajar dalam domain keterampilan. Menggunakan pendekatan pembelajaran yang menghasilkan karya berbasis pemecahan masalah (problem based learning) dapat memperkuat pendekatan saintifik dan untuk mendorong peserta didik menghasilkan karya kreatif dan kontekstual, baik individual maupun kelompok. (3) Keterampilan : diperoleh melalui kegiatan mengamati, menanya, mencoba, menalar, menyaji, dan mencipta. Seluruh isi materi (topik dan subtopik) mata pelajaran yang diturunkan dari keterampilan harus mendorong peserta didik untuk melakukan proses pengamatan hingga penciptaan. Untuk mewujudkan keterampilan tersebut perlu melakukan pembelajaran yang menerapkan modus belajar berbasis penelitian dan pembelajaran yang menghasilkan karya berbasis pemecahan masalah (problem based learning).

Dengan adanya cakupan tersebut dapat diolah dengan menggunakan model pembelajaran PBL, yang dapat meliputi proses: (1) Konsep Dasar, guru menjelaskan model pembelajaran yang akan digunakan dalam pembelajaran teori induktansi yaitu model pembelajaran PBL (Problem Based Learning) agar peserta didik paham langkah-langkah yang akan dijalani selama proses pembelajaran dan memberikan teori pendukung untuk mendasari pemahaman peserta didik terhadap materi yang akan diberikan. (2) Pendefinisian masalah, guru memberikan contoh gambar untuk diamati, ditanya dan ditalar oleh peserta didik . Guru memberikan kesempatan kepada setiap peserta didik untuk secara langsung terlibat dalam proses ini yaitu peserta didik yang bertanya dan peserta didik pula yang menjawab, sehingga proses mengamati, menanya, dan menalar dapat membuat peserta didik lebih aktif untuk mencari tau permasalahan apa saja yang terdapat pada contoh gambar yang diberikan oleh guru. Setelah itu guru memberikan beberapa permasalahan untuk dipecahkan oleh peserta didik secara diskusi kelompok. (3) Pembelajaran Mandiri, peserta didik mencoba, mencari berbagai referensi atau sumber untuk memperjelas jawaban dari permasalahan yang sudah diperoleh. Peserta didik melakukan diskusi dengan teman berbeda 
kelompok untuk bertukar informasi dan berdiskusi mengenai hasil dari permasalahan yang telah diperoleh dan peserta didik dapat mendalami materi sesuai dengan permasalahan yang telah diterima sebelumnya. (4) Pertukaran pengetahuan, pada proses pertukaran pengetahuan peserta didik kembali berkelompok untuk mendiskusikan hasil temuan dari berbagai sumber. Sesama peserta didik membagi hasil temuannya pada proses pembelajaran mandiri sebagai hasil akir dalam memecahkan setiap permasalahan. Salah satu peserta didik dari setiap kelompok diskusi (tidak harus yang terbaik) diminta untuk mempresentasikan hasil diskusinya ke depan kelas. Sementara kelompok lain, menanggapi dan menyempurnakan apa yang dipresentasikan, setelah itu guru mengumpulkan semua hasil diskusi tiap kelompok dan dengan tanya jawab, guru mengarahkan semua peserta didik pada kesimpulan materi pembelajaran dan memberikan soal yang terkait dengan materi pembelajaran untuk dikerjakan tiap peserta didik, dan dikumpulkan. (5) Kegiatan penutup, guru bersama peserta didik baik secara individual maupun kelompok melakukan refleksi untuk mengevaluasi seluruh rangkaian aktivitas pembelajaran dan hasil-hasil yang diperoleh untuk selanjutnya secara bersama menemukan manfaat langsung maupun tidak langsung dari hasil pembelajaran yang telah berlangsung, melakukan kegiatan tindak lanjut dalam bentuk pemberian tugas, baik tugas individual maupun kelompok, menginformasikan rencana kegiatan pembelajaran untuk pertemuan berikutnya dan memberikan motivasi kepada peserta didik .

Penilaian proses pembelajaran menggunakan pendekatan penilaian otentik (authentic assesment) atau penilaian menggunakan portofolio yang menilai kesiapan peserta didik, proses, dan hasil belajar secara utuh yang memiliki skala penilaian 1 sampai 4. Keterpaduan penilaian ketiga komponen tersebut akan menggambarkan kapasitas, gaya, dan perolehan belajar peserta didik atau bahkan mampu menghasilkan dampak instruksional (instructional effect) dan dampak pengiring (nurturant effect) dari pembelajaran. Hasil penilaian otentik dapat digunakan oleh guru untuk merencanakan program perbaikan (remedial), pengayaan (enrichment), atau pelayanan konseling. Selain itu, hasil penilaian otentik dapat digunakan sebagai bahan untuk memperbaiki proses pembelajaran sesuai dengan Standar Penilaian Pendidikan 
(SPP). Evaluasi proses pembelajaran dilakukan saat proses pembelajaran dengan menggunakan alat: tes, angket, observasi, catatan, dan refleksi.

\section{Tanggapan Guru dan Peserta Didik}

Mengacu pada hasil observasi dan wawacancara terhadap guru, pelaksanaan pembelajaran saintifik yang dilaksanakan dalam pendekatan problem based learning memberikan gambaran bahwa kemampuan guru dalam membuka pelajaran sudah dilakukan dengan baik. Sikap guru dalam proses belajar mengajar sudah baik, namun gerakan tangan selalu menyilang didepan atau dibelakang harus dikurangi karena terlihat tidak serius dalam melaksanakan proses pembelajaran. Penguasaan bahan ajar cukup baik dapat disajikan dengan jelas sesuai dengan langkah-langkah yang direncanakan, terampil mengarahkan peserta didik, memberikan contoh-contoh materi yang dipelajari sehingga peserta didik dapat ikut aktif dan penguasaan bahan ajar dapat tersampaikan dengan baik.

Pada saat mengimplementasikan langkah-langkah pembelajaran, guru dapat memenuhi kebutuhan peserta didik yang dipersiapkan sebelum proses pembelajaran, peserta didik dapat memahami tujuan pembelajaran, memotivasi peserta didik sehingga peserta didik dan kelompoknya dapat saling bekerjasama, bertukar pikiran dalam memecahkan masalah, mempresentasikan hasil diskusi, mengarahkan peserta didik untuk memberikan kesimpulan dan menambahkan materi yang belum dijelaskan peserta didik ataupun membenarkan pernyataaan peserta didik dengan demikian peserta didik pun dapat belajar mandiri. Kemampuan menggunakan media dilakukan dengan baik sehingga guru dapat menguasai pengoperasian alat praktek. Evaluasi dilakukan dengan baik sesuai dengan RPP yang telah dibuat.

Kemampuan guru dalam menutup pembelajaran sudah baik karena guru dapat memberikan kesempatan kepada peserta didik untuk memberikan kesimpulan dan bertanya. Guru telah memberikan tugas sesuai dengan pembelajaran yang telah diberikan, menginformasikan bahan ajar berikutnya dan memotivasi peserta didik untuk terus giat belajar. Proses pembelajaran dapat membuat peserta didik aktif, 
kreatif, mandiri dan menambah wawasan. Dengan model pembelajaran PBL guru harus siap dengan wawasan materi yang selalu berkembang.

Secara keseluruhan guru mata pelajaran yang berperan sebagai observer pada penelitian ini menanggapi proses pembelajaran penerapan pendekatan saintifik melalui model pembelajaran PBL ini berjalan dengan baik karena dapat memenuhi kebutuhan peserta didik yang dipersiapkan sebelum proses pembelajaran, terdapat pemaparan tujuan pembelajaran, peserta didik dan kelompoknya dapat saling bekerjasama, bertukar pikiran dalam memecahkan masalah, mempresentasikan hasil diskusi dan mengarahkan dalam memberikan kesimpulan dengan demikian peserta didik pun dapat belajar mandiri, aktif, kreatif, dan menambah wawasan. Pendekatan saintifik melalui model pembelajaran PBL lebih mudah dibandingkan dengan model konvensional karena teori langsung dibuktikan dengan praktek dan peserta didik lebih kompeten dengan materi yang selalu dibuktikan dengan praktek. Namun pada proses pembelajaran persiapan sebelum memulai pembelajaran harus lebih matang dan lengkap, gurupun harus siap dengan wawasan materi yang selalu berkembang.

Berdasarkan hasil penilaian angket, tanggapan peserta didik sebagian besar memberikan tanggapan baik. Dari komentar yang terdapat pada lembar angket diketahui bahwa dengan pendekatan saintifik melalui model pembelajaran PBL ini peserta didik dapat menyampaikan pendapatnya dengan baik, peserta didik dapat mengetahui seluruh jawaban permasalahan dari pembelajaran mandiri dan pertukaran pengetahuan pada saat diskusi kelompok, peserta didik dapat berinteraksi dengan baik antara sesama peserta didik maupun kepada guru dan peserta didik secara keseluruhan aktif melaksanakan langkah-langkah pembelajaran yang secara keseluruhan berpusat kepada peserta didik .

\section{KESIMPULAN}

Pada RPP berbasis pendekatan saintifik melalui model pembelajaran PBL berhasil memotivasi dan menanamkan sikap internal pada peserta didik. Tahap-tahap pendekatan saintifik dapat meningkatkan kemampuan peserta didik dalam mengamati, menanya, menalar, mencoba dan mengkomunikasikan temuannya, sehingga 
berdampak positif terhadap kemampuan soft skill-nya. Penilaian berbasis portofolio dirasakan lebih objektif dan otentik menilai kinerja peserta didik.

\section{DAFTAR PUSTAKA}

Aman Yadav, Dipendra Subedi Psychometrician, Mary A. Lundeberg, Charles F. Bunting, 2011, Problem-based Learning: Influence on Students' Learning in an Electrical Engineering Course, Journal of Engineering Education , Volume 100, Issue 2, p 253-280. DOI: 10.1002/j.2168-9830.2011.tb00013.x

Frans Ronteltap \& Anneke Eurelings, 2002, Activity and Interaction of Students in an Electronic Learning Environment for Problem-Based Learning, Distance Education, Volume 23, Issue 1. DOI:10.1080/01587910220123955.

Karim J. Nasr, C. Duane Thomas, 2004, Student-centered, Concept-embedded Problem-based Engineering Thermodynamics, International Journal Engineering Education, Volume 20, No 4, p 660 - 670.

Permana, Lis \& Purtadi. (2010). Pembelajaran Kimia Tematik Pada Mata Kuliah Kimia Dasar Sebagai Model Pembelajaran Berbasis Masalah. Jurnal Cakrawala Pendidikan Th. XXIX, No.3

Permendikbud. (2013). Jurnal Lampiran Peraturan Menteri Pendidikan dan Kebudayaan Republik Indonesia Nomor 65 Tahun 2013 Tentang Standar Proses Pendidikan Dasar dan Menengah

S. M. Said, F. R. Mahamd Adikan, S. Mekhilef \& N. Abd Rahim, 2005, Implementation of the Problem-Based Learning Approach in the Department of Electrical Engineering, University of Malaya, European Journal of Engineering Education Volume 30, Issue 1. DOI:10.1080/03043790512331313895. 